\title{
Within-colony size variation of foragers and pollen load capacity in the stingless bee Melipona quadrifasciata anthidioides Lepeletier (Apidae, Hymenoptera)
}

\author{
M. Ramalho ${ }^{a}$, V.L. Imperatriz-Fonseca ${ }^{b^{*}}$, T.C. Giannini ${ }^{\mathrm{b}}$ \\ aDepto. de Botânica do Instituto de Biologia da Universidade Federal da Bahia, Salvador, \\ CEP 40170-240, Bahia, Brazil \\ ${ }^{\text {b}}$ Depto. de Ecologia Geral, Instituto de Biociências, Universidade de São Paulo, \\ CEP 05508-900 São Paulo, Brazil
}

(Received 6 February 1997; accepted 28 January 1998)

\begin{abstract}
Within-nest worker size variation in the eusocial stingless bees is a contingent phenomenon of unknown adaptive value. We assume that the magnitude of variation represents a compromise between a minimum population of foragers and foraging efficiency at colony level. In Melipona quadrifasciata, worker size was found to vary according to colony conditions, and the pollen carrying efficiency of an individual was related to its size. On average, the foragers from a weak colony are smaller and are able to carry greater amounts of pollen per unity of body weight ('load capacity') than the larger foragers from a strong colony. The allometric variation of the corbicula (the pollen carrying structure in the hind tibia) contributes to the observed decrease in pollen load capacity with increased body size. By higher pollen intake per worker, the colonies with smaller bees could increasing the rate of brood production and colony population recovery after population crashes. $\odot$ Inra/DIB/AGIB/Elsevier, Paris
\end{abstract}

Melipona quadrifasciata / stingless bees / worker size / pollen load / allometric variations

\section{INTRODUCTION}

Body size variation within the worker caste in colonies of eusocial Hymenoptera is related to task specialization at the individual level and variability of tasks performed at colony level [16]. The range of within-colony body size variation is the releaser to polymorphism in eusocial insects. Polymorphism is a well-docu-

\footnotetext{
* Correspondence and reprints

E-mail: vlifonse@usp.br
} 
mented phenomenon in colonial invertebrates and some explanations have been proposed for its relative rarity among social insects [7]. Because worker body size variation is not enough to give rise to polymorphism in social bees, it has been viewed as a contingent phenomenon with unknown adaptive value.

The stingless bees Meliponinae, a widespread and highly diverse eusocial Apidae group [1], show subtle withincolony worker size variation [14] and division of labor coupled with age polyethism [11]. Kerr et al. [13] related a queen differentiation with minimum female body size in Melipona quadrifasciata anthidioides, and suggested that poor feeding conditions in the colony would produce smaller workers and decrease the queento-worker ratio. It has been suggested (Velthuis, pers. comm.) that the body size of the previous worker generation that builds the cells determines the brood cell size and the newborn worker size distribution. If so, a worker size should be conservative and irrespective of colony condition. The direct manipulation of the nutritional condition of larvae (e.g. food quantity) probably determines a worker body size rather than the manipulation of brood cell size.

Recently, Ramalho et al. [18] observed the relationship between a forager body weight and pollen load weight in a study of flower constancy of stingless bees (Meliponinae, Apidae). They used the pollen weight/forager body weight ratio (pollen load capacity) as a relative measure of the forager's pollen carrying efficiency among species with body sizes ranging from 4 to $100 \mathrm{mg}$. They found that the smaller the worker the higher its pollen load capacity, and suggested that variation in forager size would have an adaptive value at the colony level during population crashes: for instance, a larger population of smaller workers could be produced by the same quantity of food during food stress conditions.
To support this hypothesis, we measured the within-colony body size variation of the stingless bee $M$. q. anthidioides Lepeletier and compared the efficiency of pollen carrying between small and large foragers, from weak and strong colonies.

\section{MATERIALS AND METHODS}

Foragers of two colonies of $M . q$. anthidioides, with Eucalyptus pollen loads were captured at the nest entrance, during the same period of time. They were individually maintained in snapcap vials and anesthetized below $0^{\circ} \mathrm{C}$ for $5 \mathrm{~min}$ to be weighed. The bees were weighed with and without their pollen loads in an analytical Sartorius balance to an accuracy of $0.1 \mathrm{mg}$. The presence of nectar in the workers, crop was checked by pressing their abdomen against absorbent paper and individuals with both nectar and a pollen load were discarded. The corbicula area of 60 bees was measured under a stereoscopic microscope Wild M8 using the image analyser 'Mini-mop (Kontron-Bildanalyse)'

We use the terms weak and strong to specify the relative apparent condition of such colonies, without any assumption about their growth or reproductive potential. The strong colony was larger, more populated by larger workers, and had a larger brood comb and numerous larger pollen and honey pots than the weak colony.

We used a $t$-test to comparare the average forager weight of the weak and the strong colony of $M$. q. anthidioides. The pollen load capacity and the tibia area per body weight were plotted against body weight. For allometric comparison, we transformed the cubic (pollen load weight) and square (tibia area) dimensions to linear dimensions by calculating the respective root data. We calculated the regression lines and coefficients.

\section{RESULTS}

The measured body structures of the M. quadrifasciata foragers (table I) were significantly correlated with body weight and with each other. Obviously, the correlation values depended on the order of 
Table I. Average foragers' morphometric data from a strong and a weak colony of the stingless bee Melipona quadrifasciata anthidioides Lepeletier (Mqa). Load capacity is the ratio between pollen load weight per worker weight (the pollen weight unit that a forager is able to carry relative to its body weight unit). The average worker sizes was larger in the strong colony $(t=-22.426 ; P<0.01)$. The linear correlation values between the bee morphometric data are significant $(P<0.05)$. By contrast, the pollen weight and load capacities were correlated only with bee weight.

\begin{tabular}{|c|c|c|c|c|c|c|}
\hline $\begin{array}{l}\text { Colony } \\
\text { condition }\end{array}$ & $\begin{array}{l}\text { Body weight } \\
\text { (g) }\end{array}$ & $\begin{array}{l}\text { Head width } \\
\text { (mm) }\end{array}$ & $\begin{array}{l}\text { Thorax width } \\
\text { (mm) }\end{array}$ & $\begin{array}{c}\text { Tibia area } \\
\left(\mathrm{mm}^{2}\right)\end{array}$ & $\begin{array}{l}\text { Pollen load weight } \\
\text { (g) }\end{array}$ & $\begin{array}{l}\text { Load capacity } \\
\text { (g) }\end{array}$ \\
\hline Strong $(n=30)$ & $0.0873 \pm 0.0129$ & $2.52 \pm 0.14$ & $3.94 \pm 0.12$ & $3.64 \pm 0.07$ & $0.0099 \pm 0.0055$ & $0.1236 \pm 0.0323$ \\
\hline Weak $(n=30)$ & $0.0640 \pm 0.0078$ & $2.15 \pm 0.11$ & $3.68 \pm 0.09$ & $3.42 \pm 0.12$ & $0.0109 \pm 0.0045$ & $0.1777 \pm 0.0342$ \\
\hline \multicolumn{7}{|c|}{ Linear correlation values $(\mathrm{r}) ;[\mathrm{rc}=0.252 ; P<0.05(n=60)]$} \\
\hline & & $\begin{array}{c}\text { Thorax } \\
\text { width }\end{array}$ & $\begin{array}{c}\text { Tibia } \\
\text { area }\end{array}$ & $\begin{array}{l}\text { Head } \\
\text { width }\end{array}$ & $\begin{array}{c}\text { Bee } \\
\text { weight }\end{array}$ & \\
\hline & Pollen weight & -0.06 & -0.2079 & -0.0339 & -0.5526 & \\
\hline & Load capacity & -0.2466 & -0.4114 & -0.239 & -0.7135 & \\
\hline & Bee weight & 0.5845 & 0.7389 & 0.641 & & \\
\hline & Head width & 0.6 & 0.7384 & & & \\
\hline & Tibia area & 0.6457 & & & & \\
\hline
\end{tabular}

values (volume-weight, area and length). On average, the foragers from the weak colony were significantly lighter (smaller) than those from the strong one and the smaller foragers carried more pollen per unit of body weight (higher load capacity) than the larger ones.

The pollen load capacity (plc) and the tibia area per body weight ratio (ta/bw) were both correlated with body weight (table I; figure I), but not with the other morphometric body parameters. Therefore, the weight of pollen carried per body weight unit was mainly an outcome of the allometric development of the pollen carrying structure. However, the difference of the slope (' $b$ ' parameter) between plc and $\mathrm{ta} / \mathrm{bw}$ regression lines (figure 1) suggests that other factors contributed to the higher pollen load capacity of the smaller workers.

Figure 2 shows the weight frequencies of the 30 workers from strong, medium and weak colonies.

\section{DISCUSSION}

Although stingless bee workers from a strong nest have similar sizes, some variations occur, as Imperatriz-Fonseca et al. $[10]$ indicated by the weight variation of workers of Nannotrigona testaceicornis just after emergence. Nevertheless, size variations are more conspicuous when examined among colonies of different health.

Camillo-Atique [2] studied weak, medium and strong colonies of the stingless bee $M$. rufiventris rufiventris, establishing that some behavioral parameters, such as the rate of cell construction, provisioning and oviposition, were dependent on colony conditions. Worker flight activity was also influenced by colony condition [8,9]. Weaker colonies had a shorter period of foraging than stronger colonies in $M$. bicolor bicolor and in Schwarziana quadripunctata. Other aspects, such as brood cell size and food 
discharge rate during cell provisioning, etc., may be useful to discern the functional state of a stingless bee colony [14] which has been empirically related to the workers' body size and number within colonies. The variations in worker size among weak, medium and strong colonies of $M$. quadrifasciata are easily observed in figure 2 .
The proximate factor that causes within-nest size variation of workers is the amount of food given to the larval stages. In contrast, variation in worker size may be constrained by several factors such as a flight aerodynamics [6] and the trophic determination of female caste [24]. The latter explanation should be applied with reservation to all stingless bees

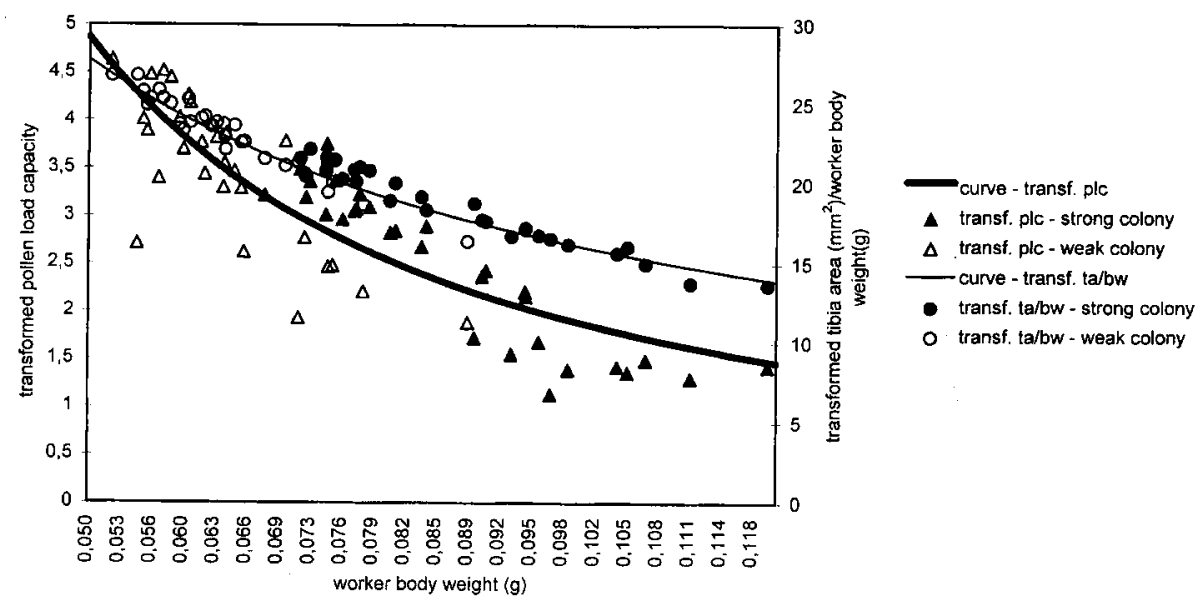

Figure 1. Frequency distribution of worker body weight for a weak ( $n=30$ individuals) and a strong ( $n=30$ ) colony of Melipona quadrifasciata anthidioides. The ' $a$ ' parameter is the ' $\mathrm{Y}$ ' intercept when body weight tends toward zero and the ' $b$ ' parameter is the slope of the regression line: $\mathrm{Y}=\mathrm{aX}{ }^{\mathrm{b}}(n=60)$. transf. plc: $\mathrm{a}=0.08 ; \mathrm{b}=-1.37(\mathrm{r}=-0.88 ; P<0.05)$; transf. ta/bw: $\mathrm{a}=2.61$; $\mathrm{b}=-0.79(\mathrm{r}=-0.97 ; P<0.05)$.

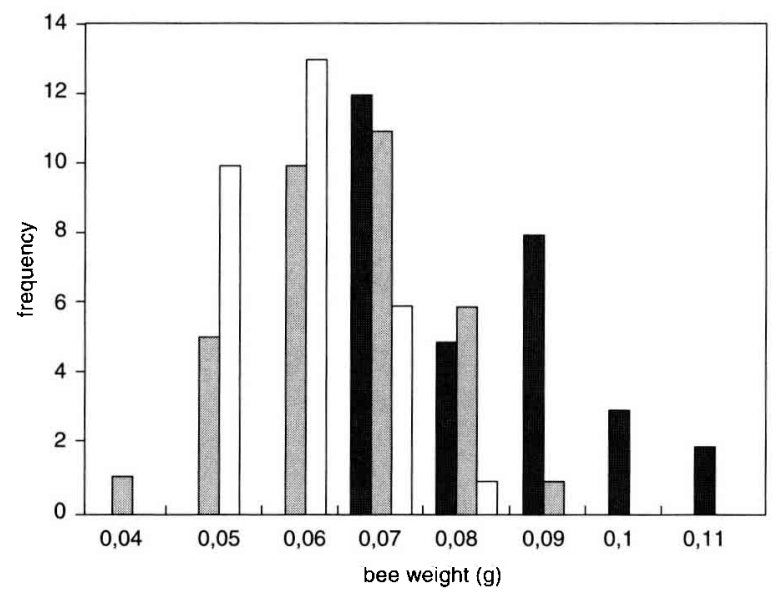

strong $(n=30)$

medium ( $n=34)$ (Ramalho et al. 1994)

$\square$ weak $(n=30)$

Figure 2. Frequencies of worker weight collected from weak $(n=30)$, medium $(n=34$ data from Ramalho et al. [18]) and strong $(n=30)$ colonies of Melipona quadrifasciata anthidioides. 
because genetic and trophic mechanisms play a role in caste differentiation [3]. For the stingless bees, there is also an inverse relationship between complexity of the recruitment system and within-nest variation in worker body size [23]. These factors explain why within-colony size variation is not so large as to produce a polymorphic worker caste. However, they do not clarify the functional role of the observed body size variation.

The approximately 400 species of stingless bees are small to medium sized bees (3-13 $\mathrm{mm}$ in length) with considerable variation in colony population size (from several hundreds up to more than ten thousands workers in a colony). They also exhibit a high rate of brood production and require a high pollen intake. Due to their restricted colony home range [ 12 , $15,19,22]$ and the high local plant diversity in tropical habitats, they become particularly exposed to the turnover of food supply in their colony surroundings. In such a context the reduction of worker size, through quantity of larval food in the cell, would be a good alternative to deal with food deprivation if it prevents an additional decline in the colony population. The gain achieved by producing small workers might be outweighed by negative side-effects: the small bees could retrieve food from a profitable food source at a higher cost across a given distance than could the large bees because the former may have a higher energy consumption per time of foraging [21]. Most of all, the higher energy consumption of the small workers during foraging activity may cause a shortened life span [20].

In summary we hypothesize that stingless bee colonies adjust their average forager size after food deprivation periods to maximize pollen foraging efficiency. In such a situation it would be better to produce many smaller workers because worker size is negatively correlated with the pollen load capacity - (plc) (figure l); that is, the smaller the forager the higher the amount of pollen it can carry per unit of body weight. In a study of food gathering by bumblebees, Free [5] observed that "several of the smaller bees were found to have collected relatively large loads of pollen for their size". The smaller foragers also collected larger loads of sugar syrup in proportion to their body size.

Obviously, below a maximum value of plc for a given body size, the individual foragers could adjust their loads, depending on extrinsic factors and risk sensitive behaviors, which caused a broad dispersion of plotted points (figure l). Fewell and Winston [4] provided evidence that in Apis mellifera the pollen foragers adjust their load size and trip time in relation to the colony's pollen storage levels. In colonies of the bumblebee Bombus terricola, deprived of pollen, the foragers carried heavier pollen loads instead of increasing the number of foraging trips [17]. The stingless bees seem to respond in a similar way to a reduced foraging period. It is common to observe the workers arriving at the nest entrances with very large pollen loads after periods of shortened foraging activities (cold, rainy days, etc.). At this time, we do not know how the size of the pollen load is related to the age of the worker and its foraging experience.

Observational data on several stingless bee species suggest that reduction in worker size and the decrease in colony population takes place after a few weeks of colony exposure to stress conditions (e.g. after transport of colonies from the wild to laboratory conditions with a loss in forager population, and after brood comb manipulations). Probably there is a decrease in the amount and quality of larval food in these weak colonies, as Lacerda et al. [14] observed in Geotrigona inusitata. We hypothesize that these simultaneous changes would be adaptive; that is, they contribute to colony survival when pollen supply is low for two reasons: 1) a higher 
number of workers discharge smaller amounts of larval food in each brood cell [14] so a higher proportion (not necessarily a higher absolute number) of individuals within the low populated colony may be involved in food discharging; 2) as a result, a smaller proportion of workers might be available for pollen foraging. Therefore the weak colonies would be best served if their workers are small because with the same available food they would produce more small bees than large bees, and the smallest ones would carry greater amounts of pollen per body biomass.

\section{ACKNOWLEDGMENTS}

We acknowledge support from the $\mathrm{CNPq}$ (521776/96.1). The authors are grateful to Dr H.H.W. Velthuis and Dr A.M.P. Kleinert for their suggestions, as well as to the anonymous referees.

Résumé - Variation intra-colonie de la taille des ouvrières et de la capacité de charge en pollen chez l'abeille sans dard Melipona quadrifasciata anthidioides Lepeletier (Hymenoptera : Apidae). La variation de la taille des ouvrières à l'intérieur de la colonie est un phénomène aléatoire chez les abeilles sans dard, dont on ne connaît pas la valeur adaptative. Nous pensons que l'étendue de la variation représente un compromis entre une population minimale de butineuses et l'efficacité du butinage au niveau de la colonie. Pour étayer cette hypothèse, nous avons mesuré la variation intra-colonie de la taille corporelle, du poids corporel et de la surface de la corbicule chez l'abeille sans dard $M$. q. anthidioides et comparé l'efficacité du transport de pollen par des butineuses de petite taille et des butineuses de grande taille issues de deux colonies. Trente butineuses ont été capturées respectivement à l'entrée du nid d'une colonie faible et d'une colonie forte. Les termes « faible », «moyenne» et «forte » désignent la condition relative apparente des colonies en termes de taille des ouvrières, diamètre du nid à couvain, effectif du nid... Chez M. q. anthidioides la taille des ouvrières varie en fonction des conditions apparentes de la colonie et l'efficacité du transport de pollen d'un individu est en relation avec sa taille (tableau $I$ ). Les butineuses d'une colonie faible sont en moyenne plus petites et capables de transporter de plus grandes quantités de pollen par unité de poids corporel (forte capacité de charge en pollen) que les butineuses plus grandes d'une colonie forte. Les colonies de taille moyenne présentent des valeurs intermédiaires pour le poids des ouvrières (figure 2). La capacité de charge en pollen et le rapport de la surface du tibia postérieur au poids corporel (ta/bw) sont corrélés négativement avec le poids corporel (figure 1). La variation allométrique de la corbicule contribue à la diminution observée de la capacité de charge en pollen par rapport à la taille corporelle. La variation intra-colonie observée de la taille corporelle moyenne d'une ouvrière aurait une valeur préadaptative chez les abeilles sans dard. En augmentant le taux de récolte de pollen par unité de travail, les colonies qui ont de petites ouvrières pourraient accroître le taux de production de couvain et accélérer le rétablissement de l'effectif de la colonie, lorsque celle-ci s'est effondrée suite à des manques saisonniers de nourriture dans la zone de butinage des petites colonies, à la fondation de nouvelles colonies ou à la prédation du nid. (C) Inra/DIB/AGIB/Elsevier, Paris

Melipona quadrifasciata / abeille sans dard / taille corporelle / récolte pollen / variation allométrique

\footnotetext{
Zusammenfassung - Größenvariation und Pollenbeladungsfähigkeit von Sammlerinnen innerhalb von Völkern
} 
der Stachellosen Biene Melipona quadrifasciata anthidioides Lepeletier (Apidae, Hymenoptera). Innerhalb von Völkern der eusozialen Stachellosen Bienen ist die Variation der Arbeiterinnengröße eine durchgehende Erscheinung; ihr adaptiver Wert ist allerdings unbekannt. Wir nehmen an, daß das Ausmaß dieser Variation einen Kompromiß zwischen minimaler Sammlerinnenpopulation in den Völkern und der Sammeleffizienz auf dem Volkslevel darstellt. Zur Stützung dieser Hypothese haben wir die Körpergröße, das Körpergewicht und die Körbchengröße innerhalb von Völkern der Stachellosen Biene Melipona quadrifasciata anthidioides Lepeletier vermessen sowie die Effizienz des Polleneintrags von kleinen und großen Arbeiterinnen zwischen zwei Völkern verglichen. Am Nesteingang eines schwachen sowie eines starken Volkes wurden jeweils 30 Sammlerinnen abgefangen. Die Bezeichnungen 'schwach', 'mittelstark' und 'stark' beziehen sich hierbei auf den augenscheinlichen Zustand der Völker, wie die Größe der Arbeiterinnen, den Durchmesser der Brutwaben, die Individuenzahl etc. Bei Melipona quadrifasciata variiert die Arbeiterinnengröße mit dem Zustand der Völker, hierbei ist die Polleneintragskapazität eines Einzeltiers von seiner Größe abhängig (Tabelle I). Im Mittel sind die Sammlerinnen eines 'schwachen' Völkchens kleiner und sind in der Lage relativ zu ihrem Körpergewicht größere Mengen von Pollen einzutragen (hohe Pollenbeladungsfähigkeit) als die größeren Arbeiterinnen eines "starken" Volkes. Mittelstarke Völker zeigen mittlere Gewichte der Arbeiterinnen $(A b b 2)$. Die Pollenbeladungsfähigkeit und das Verhältnis der Fläche der Tibia des Hinterbeins zum Körpergewicht (ta/bw) waren beide negativ mit dem Körpergewicht korreliert $(A b b$ 1). Die allometrische Variation der Corbiculae trägt daher zu der beobachteten Abnahme der Pollenbeladungsfähigkeit relativ zum Körpergewicht bei. Der in den Völkern beo- bachteten Variation der mittleren Körpergröße der Arbeiterinnen könnte bei den Stachellosen Bienen ein prädativer Wert zukommen. Hierdurch könnte die auf die Arbeitseinheit bezogene höhere Polleneintragsrate in kleinen Völkern die Brutproduktion beschleunigen und damit die Erholung der Population nach Volkszusammenbrïchen verbessern, wie diese durch saisonale Nahrungsknappheit in dem begrenzten Futtersuchareal kleiner Völker, durch die Gründung neuer Nester, und durch Nestberäuberung auftreten. (c) Inra/DIB/AGIB/Elsevier, Paris

\section{Melipona quadrifasciata / Stachellose Bienen / Arbeiterinnengröße / Pollen- beladungsfähigkeit / allometrische Variation}

\section{REFERENCES}

[1] Camargo J.M.F., Pedro S., Systematics, phylogeny and biogeography of the Meliponinae (Hym., Apidae): a mini-review, Apidologie 23 (1992) 509-522.

[2] Camilo-Atique C., Variabilidade do comportamento de Melipona rufiventris rufiventris (Hymenoptera, Apoidea), Dissertação de Mestrado, Ribeirão Preto, 1974

[3] Engels W., Imperatriz-Fonseca V.L., Caste development, reproductive strategies, and control of fertility in honeybees and stingless bees, in: Engels W. (Ed.), Social Insects, An Evolutionary Approach to Castes and Reproduction, Springer-Verlag, Berlin, 1990, pp. 167-230.

[4] Fewell J.B., Winston M.L., Colony state and regulation of pollen foraging in the honeybee, Apis mellifera, L. Behav. Ecol. Sociobiol., 300 (1992) 387-393.

[5] Free J.B., The collection of food by bumblebees, Insectes Soc. 2 (1955) 303-311.

[6] Hartfelder K., Engels W., Allometric and multivariate analysis of sex and caste polymorphism in the Neotropical stingless bee, Scaptotrigona postica, Insectes Soc. 39 (1992) 251-266.

[7] Harvell C.D., The evolution of polymorphism in colonial invertebrates and social insects, $Q$. Rev. Biol. 69 (1994) 155-185. 
[8] Hilário S.D., Imperatriz-Fonseca V.L., A influência do estado da colônia na atividade de vôo de Melipona bicolor bicolor, Anais do $2^{\circ}$ Encontro sobre abelhas, Ribeirão Preto, 1996 , p. 285 .

[9] Imperatriz-Fonseca V.L., Darakjian P., Flight activity of Schwarziana quadripunctata: influence of environmental factors, in: Abstracts of IV Behavioral Ecology Congress, Nottingham, 1994, p. 86.

[10] Imperatriz-Fonseca V.L., Cruz-Landim C., Moraes R.L.M.S., Dwarf gynes in Nannotrigona testaceicornis (Apidae, Meliponinae)behaviour, exocrine gland morphology and reproductive status, Apidologie 28 (3) (1997) 113-122.

[11] Inoue T., Salmah S., Sakagami S.F., Individual variations in worker polyethism of the Sumatran stingless bee, Trigona (Tetragonula) minangkabau (Apidae, Meliponinae), Jpn. J. Entomol. 64 (3) (1996) 641-668.

[12] Kerr W.E., Bionomy of Meliponids, VI. Aspects of food gathering and processing in some stingless bees, Food gathering in Hymenoptera, Symp. Entomol. Soc. Am., Detroit (1959) p. 24-32.

[13] Kerr W.E., Stort A.C., Montenegro M.J., Importância de alguns fatôres ambientais na determinação das castas do gênero Melipona, Anais Acad. Brasil Ciênc 38 (1966) 149-168.

[14] Lacerda L.M., Zucchi R., Zucoloto F.S., Colony condition and bionomic alterations in Geotrigona inusitata (Apidae, Meliponinae), Acta. Biol. 20 (1991) 109-123.

[15] Michener C.D., The Social Behavior of the Bees, A Comparative Study, Harvard University Press, Cambridge, 1974.
[16] Oster G.F., Wilson E.O., Caste and ecology in the social insects, Princeton Univ. Press., New Jersey, 1978.

[17] Plowright R.C., Thomson J.D., Lefkovitch L.P., Plowright C.M.S., An experimental study of the effect of colony resource level manipulation on foraging for pollen by worker bumble bees (Hymenoptera: Apidae), Can. J. Zool. 71 (1993) 1393-1396.

[18] Ramalho M., Giannini T.C., Malagodi-Braga K.S., Imperatriz-Fonseca V.L., Pollen harvest by stingless bee foragers (Hymenoptera, Apidae, Meliponinae), Grana 33 (1994) 239-44.

[19] Roubik D.W., Aluja M., Flight ranges of Melipona and Trigona in tropical forest, J. Kans. Entomol. Soc. 56 (1983) 217-222.

[20] Schmid-Hempel P., Wolf T.J., Foraging effort and life span in a social insect. J. Anim. Ecol. 56 (1988) 209-18.

[21] Seeley T.D., The Wisdom of the Hive, Harvard University Press, Cambridge, 1995.

[22] van Nieuwstadt M.G.L., Iraheta C.E.R., Relation between size and foraging range in stingless bees (Apidae, Meliponinae), Apidologie, 27 (4) (1996) 219-228.

[23] Waddington K.D., Herbst L.H., Roubik D.W. Relationship between recruitment systems of stingless bees and within-nest worker size variation, J. Kans, Entomol. Soc. 59 (1986) 95-102.

[24] Wheeler D.M., Developmental and physiological determinants of caste in social Hymenoptera: evolutionary implications, Am. Nat. 128 (1986) 13-34. 